\title{
Why is Lake Urmia Drying up? Prognostic Modeling With Land-Use Data and Artificial Neural Network
}

\author{
Akbar Rahimi ${ }^{1 *}$ and Jürgen Breuste ${ }^{2}$ \\ ${ }^{1}$ Department of Landscape Engineering, University of Tabriz, Tabriz, Iran, ${ }^{2}$ Research Group for Urban and Landscape Ecology, \\ Department of Geography and Geology, University of Salzburg, Salzburg, Austria
}

Lake Urmia (LU) is considered as the largest salt water lake in Iran and has severe restrictions on water resources and becoming a salt lake increasingly. The LU drought will Couse ecological, health, social and economic problems. Land-use change and the increasing of salt areas evaluated in this work using satellite imagery. We evaluated the present situation and changes of the lake area in the past and further changes until 2025. The results indicated that from 1987 to 2000 , the process of change has slowed down and less than $2 \%$ of the lake's water area was reduced, and from 2000 to 2010, these shrinking processes were faster and more than $28 \%$ of the lake water area disappeared. The intensity of the shrinking from 2010 to 2014 is very severe. Using the Land Transformation

OPEN ACCESS

Edited by:

Anik Bhaduri,

Griffith University, Australia

Reviewed by: Saumitra Mukherjee, Jawaharlal Nehru University, India Mahsa Jahandideh Tehrani, Griffith University, Australia

*Correspondence: Akbar Rahimi akbar.rahimi@gmail.com

Specialty section:

This article was submitted to Environmental Informatics and Remote Sensing,

a section of the journa Frontiers in Environmental Science

Received: 09 September 2020

Accepted: 20 July 2021

Published: 31 August 2021

Citation:

Rahimi $A$ and Breuste $J$ (2021) Why is Lake Urmia Drying up? Prognostic Modeling With Land-Use Data and

Artificial Neural Network.

Front. Environ. Sci. 9:603916. doi: 10.3389/fenvs.2021.603916
Model, the continuation of the changes was modeled until 2025. The results of the modeling indicate the conversion of the water lake to salt lake in this period, and in the north part, the shallow waters occupy $0.7 \%$ of the total lake area. The result shows that climate change was not the significant factors for drying up of the lake but human factors such as building dams to store water for irrigation, increasing groundwater use by established deeper wells for agricultural irrigation were the important factors for drying. With changing of management of the waters leading to the lake and the transfer of new water resources to the lake between 2014 and 2016, the area of the lake increased to a double. It was evident that by proper planning and managing of water resources, the lake's restoration can be achieved.

Keywords: Urmia lake, land-use change modeling, remote sensing, GIS, artificial neural network

\section{INTRODUCTION}

For a long time, severe climate change, reduced precipitation and limitations of usable water have caused people manage the water resources for agricultural, urban and industrial functions by building a variety of dams. But today, the study of changes in the lake water level to protect them because of the importance, nature, and position of these lakes, which is a factor in the survival and conservation of natural heritage. In recent years, study of lake changes has found a special status among countries at the national and regional levels (Rasouli, et al., 1998). Therefore, special attention has been paid to coastal areas, especially the environment of lakes as ecological environments (Jensen, 1996). In recent decades, one of the main studies about world changes has focused on landuse change crises. Because land-uses change is a significant factor in global change. So that land-use change studies have given special attention to studies of natural disasters and global warming. Landuse changes have effect on climate change (Jeong, 2018), environmental pollution (Lee, 2008; Rahimi, 
2016), biodiversity and ecosystem services (Breuste and Qureshi, 2011; Breuste and Rahimi, 2015; Wang, et al., 2018), biochemical cycles (Allen, et al., 2016; Lopez, et al., 2001) Life Cycle (De Rosa, 2018), and other important activities related to human activities. One of the most important land-use changes is ponds and lake drying. The drought effects of many ponds and lakes in the world are their conversion into dust concentrations. Based on the results of studies carried out by various researchers, many pond and lakes dried up in the world located in China (Ebinur Lake, Lop Nor, Aiding Lake), Central Asia (Kara-Bogaz-Gol, Aral Sea) and United States (Owens Lake, Great basin playas, Great Salt Lake) Latin America (Salinas Grandes in Argentina, Salar de Uyuni,), which have become the focus of dust production (Lake Urmia Restoration Program, 2014).

Evaluation of lakes drying up is one of the most important subjects in ecosystem challenges. Lake Urmia (LU), located in northwestern Iran, is one of the largest natural permanent hyper saline lakes in the world, formerly covered an area around $6,000 \mathrm{~km}^{2}$ before 1989 (Torabi et al., 2018; Balkanlou et al., 2020) contained about 30,000 million $\mathrm{m}^{3}$ of water (Eimanifar and Mohebbi, 2007; Shadkam et al., 2016). The lake provides important cultural, economic, aesthetic, recreational and scientific values (Abbaspour et al., 2012; Ahmadi et al., 2016). The lake area has decreased by $90 \%$ in recent decades (Pengra, 2012; AghaKouchak et al., 2015; Ghale et al., 2017; Mardi et al., 2018). The lake has been threatened by multiple anthropogenic activities, including increased agricultural activity, urban expansion, extensive construction of dams and anthropogenic changes to the lake system including a constructed causeway as well as severe climate change-induced droughts (Tourian et al., 2015; Alborzi et al., 2018). As a result, the salinity of the lake has sharply increased which is disturbing the ecosystems, local agriculture and livelihoods, regional health, as well as tourism (United Nations Environment Programme UNEP, 2012). It is of high importance to identify the responsible regional factors to develop strategies against this tremendous decline process.

Todays the use of satellite imagery to assess these changes in the earth, and in particular, the assessment of changes in coastal levels and seawater and lake waters has become widespread. Wine et al. (2019) concluded that the main reasons for shrinking Galilee Sea are expanding irrigated agriculture, doubling of groundwater pumping rates within the basin, and increasing of the area of standing and impounded waters. While the temperature increase in the basin is statistically significant and may increase transpiration evaporation. The results show that the return of the Galilean Sea level requires a reduction in groundwater pumping, water diversions, and agricultural water use consumption. Yapiyev et al. (2019) evaluated the water storage changes in small endothecia lakes in the northern Kazakhstan using digital elevation model, bathymetry maps and Landsat from 1986 to 2016. The results show that the water storage decline in lakes for those 30 years has been relatively modest. Shortandy and Ulken Shabakty water volumes have declined during the past 3 decades.

Much research has been done about LU change, Tracing hydro-climatic and land-use changes to better understand the Lake Urmia tragedy (Khazaei et al., 2019), crisis and

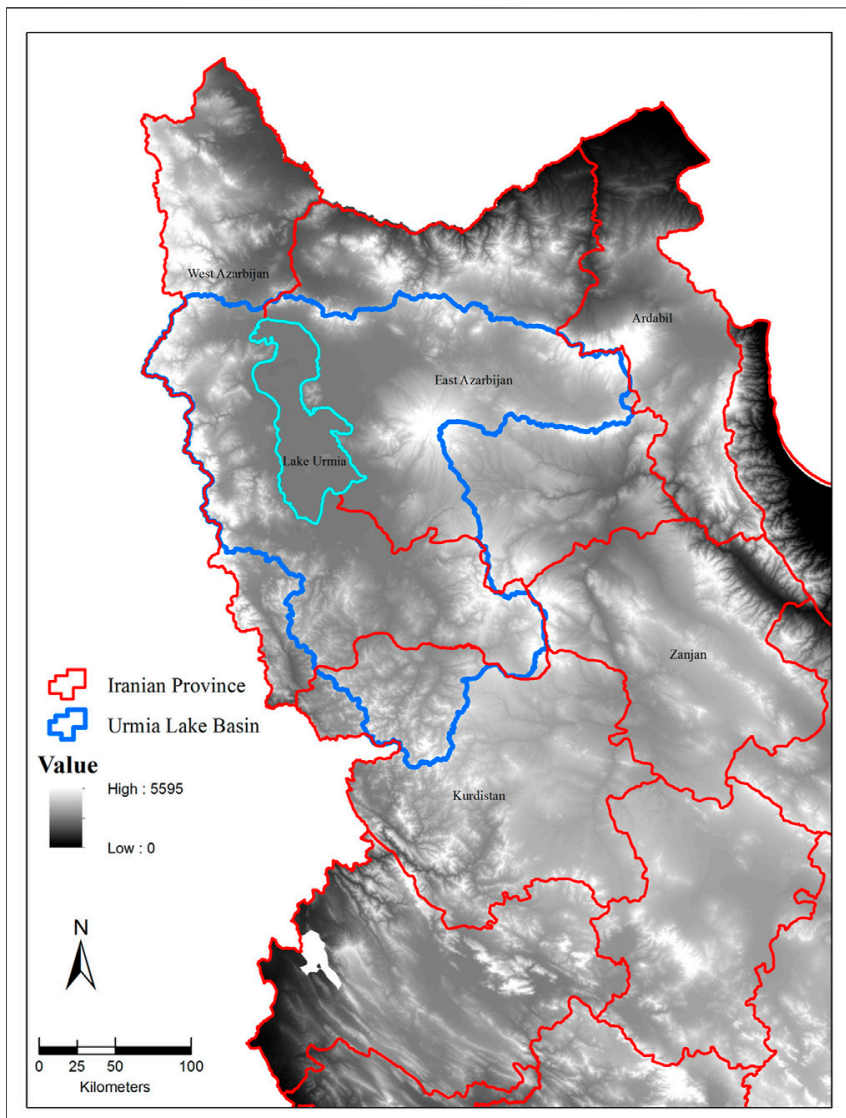

FIGURE 1 | Location of LU in Iran (author's illustration).

restoration plan (Danesh Yazdi and Ataei Ashtarian, 2019), restoration progress using ground-based and space borne observations (Saemian et al., 2021), water resources management under future land use change (Shirmohammadi et al., 2020), restoration success story (Nikraftar et al., 2021) and diverse restoration objectives (Sima et al., 2021). But a little work has been done on why the lake was drying. In this paper, land cover and land-use changes in LU from 1987 to 2014 are evaluated in a first step followed by identification of reasons for these changes and a future modeling of expectable development.

\section{MATERIAL AND METHODS}

\section{Case study}

The LU located in the northwest of Iran and limited to two Iranian provinces of East and West Azerbaijan (Figure 1). It was the largest inland body of saltwater in the Middle East (Zarghami, 2011). The length of the lake varies is from $130 \mathrm{~km} / \mathrm{h}$ to $146 \mathrm{~km}$, and also the widest part is $58 \mathrm{~km}$ and the narrowest part that located in the midst of Zanbil Mountain and Islamic Island, is $15 \mathrm{~km}$. The basin area of the lake is $52,355 \mathrm{~km}^{2}$. LU has 102 small and big islands, which the largest island is the Goyondaghy Island with $2.3 \mathrm{~km}^{2}$, and is the only islands where freshwater is found. 
The main water Source Rivers in LU basin are Aji Chay, Simineh and Zarrineh rivers (Sharifi, et al., 2018).

\section{Land Transformation Model}

In recent years, land-use change modeling has become an essential tool for urban planners, economists, ecologists, and resource managers (Rahimi, 2016). Pijanowski et al. (2000) have developed new software (Land Transformation Model (LTM) to modeling land-use/ cover change based on geographic information systems (GIS), artificial neural network (ANN) routines, remote sensing, and customized geospatial tools.

The LTM model is a computer application and it has four consecutive steps for simulation: in the first step, the predict variables data coded to create spatial layers. In the second step, Implementing spatial rules base of predictor variables to land-use transitions for each location in an area, in third step, combining all input grids using one of the three techniques, including multicriteria evaluation, ANNs, and logistic regression; and in the final step, scaling the quantity of transitions to create a time series of probable future land-uses (Pijanowski et al., 2000; Rahimi, 2016).

\section{Data collection and analyzes}

Landsat satellite images $(5,7$ and 8$)$ in the study period were obtained from EarthExplorer (EE) of (United States Geological Survey USGS (2018). In the first step and after geometric correction, the images were classified using ERDAS IMAGINE 2014 software in four class (deep water, shallow water, island and vegetation, and salt surfaces) base on supervised classification. Then, the classification result is exported to Arc GIS 10 software for producing final maps.

To predict LU land-use class changes in 2025, we used 2010 and 2014 land-use classified as an input and output class's respectively using LTM software packages (Department of forestry and natural resource, 2018). The metrological data were average monthly temperature, maximum monthly temperature, minimum monthly temperature, sum monthly precipitation, the human factors data were agricultural landuse change, construction of dams and deep wells.

Designing of the network architecture is based on the approximation theory of Kolmogorov (1957), and the structure of ANN with 25 neurons and one hidden layer had the best performance. ANN trained by scaled-conjugate-gradient (trainscg) training algorithm has implemented to model. In the first all of maps for modeling in LTM should be converted to grid format and then converted to ASCII format (Rahimi, 2016). After preparation of data in ASCII format, in the first step, ANN is trained using input variables, output variable (land-use map 2014) with 250,000 Cycles Learning (CL) to reduce Root Mean Square (RMS) and overtraining. In the second step, ANN was tested using variables in the last step and a real change map that was produced in the training step. In the forecasting step, a transformation land-use is calculated based on the changing rate from 2010 to 2014 to forecast land-use change in 2025. The size and number of cells in all of maps and variables must be the same (Rahimi, 2013). Therefore, we prepared the maps in $200^{*} 200$ cells with same rows and columns. Figure 2. Show the methodological process for producing probability land- use change map. For assessment of the simulation and prediction process, RMS, percent correct metric (PCM) and Kappa Coefficient (KC) were calculated from the following equations:

$$
\mathrm{RMS}=\frac{1}{\mathrm{~N}} \sum_{i=1}^{N}(\mathrm{Pi}-\mathrm{Oi}) 1 / 2
$$

RMS = root mean square $\mathrm{Oi}=$ original data $; \mathrm{O}=$ predicted data; $\mathrm{N}=$ number of samples

$$
\mathrm{PCM}=\frac{\mathrm{TP}}{\mathrm{TCN}} \times 100
$$

PCM = percent correct metric TP (real change and predicted change) $=$ true positive $\mathrm{TCN}=$ transition cell number

Карpa $=\frac{\left(\left(\frac{T N}{G T}\right)+\left(\frac{T P}{G T}\right)\right)-\left(\left(\left(\frac{S N}{G T}\right) \cdot\left(\frac{R N}{G T}\right)\right)+\left(\left(\frac{S P}{G T}\right) \cdot\left(\frac{R P}{G T}\right)\right)\right)}{1-\left(\left(\left(\frac{S N}{G T}\right) \cdot\left(\frac{R N}{G T}\right)\right)+\left(\left(\frac{S P}{G T}\right) \cdot\left(\frac{R P}{G T}\right)\right)\right)}$

$\mathrm{TN}=$ True Negative (no real change and no predicted change) $\mathrm{FN}=$ False Negative (no real change but change predicted by the model)

FP = False Positive (real change but not predicted by the model) $\mathrm{TP}=$ True Positive (real change and predicted change)

$(\mathrm{SN}=\mathrm{TN}+\mathrm{FN})$ Simulated Negative

$(\mathrm{SP}=\mathrm{FP}+\mathrm{TP}$ (Simulated Positive

$(\mathrm{RN}=\mathrm{TN}+\mathrm{FP})$ Real Change Negative

$(\mathrm{RP}=\mathrm{FN}+\mathrm{TP})$ Real Change Positive

$(\mathrm{GT}=\mathrm{TN}+\mathrm{FN}+\mathrm{FP}+\mathrm{TP})$

In the final process, land-use map 2016 for evaluation the activities performed to revitalize the lake were evaluated. For assessment of metrological factors, the synoptic annual mean participation and annual mean temperature data are used for LU basin (East Azerbaijan, West Azerbaijan and Kurdistan provinces in the northwest of Iran) from 1987 to 2014 using Iranian meteorological office data (Iranian labour News Agency, 2014). The land-use changes in the Urmia basin for two periods were interpreted from Land Sat images from Earth Explorer of United States Geological Survey (United States Geological Survey USGS, 2018). The dams and deep well data in this work are used from the LU Restoration Program studies (Lake Urmia Restoration Program, 2014).

\section{RESULTS}

\section{Assessment of Satellite Images 1987-2014}

Evaluation of satellite images from 1987 to 2000, showed that water areas changes were slow and the area decreased from $482,571.13$ to $472,562.42$ hectares. In these 13 years, the water areas reduced from 83.66 to $81.93 \%$. But from 2000 to 2010 , the change rate increased, and 162,561 hectares of water areas dried up and changed to salt marshes. In this period, the water areas decreased to $53.74 \%$ of lake limits and salt areas increased to $39.09 \%$ (the limit area for LU is 576806.95 that include water, salt and island areas). 


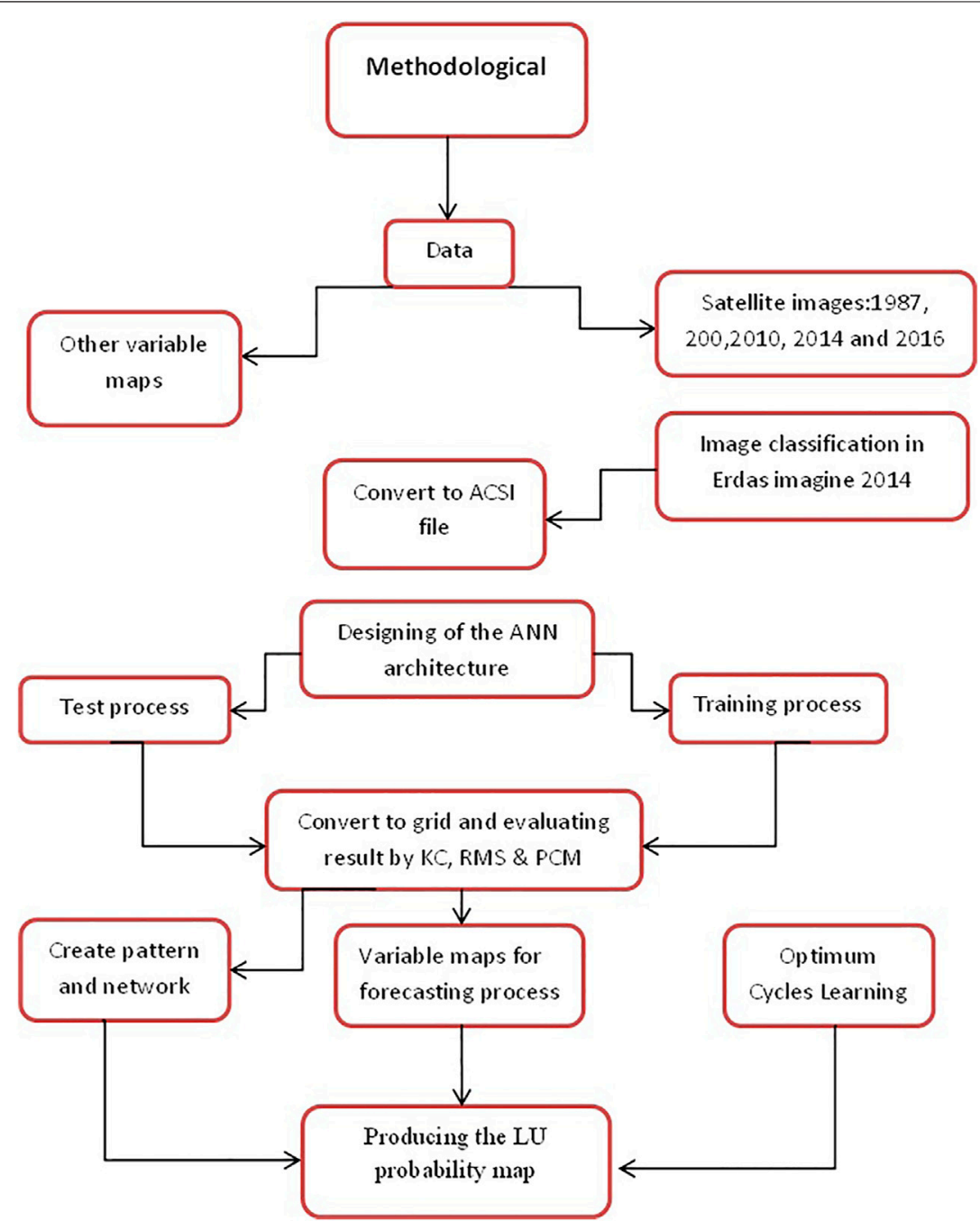

FIGURE 2 | Methodology process in LU probability land use change.

The land use class assessment for 2014 shows that the rate of change has been more severe from 2010 to 2014 . As indicated in Figure 3, the south of lake has converted to salt marsh and only in the northern part of the lake, with a less water is retained. In this period, 218,013 hectares of water areas decreased and the water areas reduced to $15.95 \%$ of Lake Limit (Figure 3; Table 1).

\section{Prediction of Land-Use/Cover Change in Lake Urmia for 2025}

Land Transformation Model (LTM) is used for lake change prediction for 2025 based on the past development (2010-2014) pattern. Satellite images for 2010 and 2014 were used as a base map in input and output for learning, test and simulation process, respectively. In the final process, LU land-use map predicted based on results in the previous stage (2010-2014).

The best RMS (0.13091), KC (70.24556) and PCM (76.45904) at $\mathrm{CL}(9,000)$ were obtained for producing the land/cover change probability map. Therefore the result of $9000 \mathrm{CL}$ is used in the test and simulation process (Table 2).

As shown in Figure 4, if the threat of drying up continued like 2010 to 2014 periods, water areas in 2025 will remain only in northwest of lake limited as shalom ponds and more than $99 \%$ of lake will change to salt marsh and the water areas decreased to $0.7 \%$ (Figure 4; Table 3). Therefore, the disturbance of ecological balance will threat the northwest of Iran and maybe the neighboring countries and this changed pattern can cause national, regional and even international crisis that not only causes environmental damage but also will affect the health status of the regional population.

\section{The Main Reason Lake Urmia Drying Meteorological Factors}

For evaluation of this factor, the participation and temperature in 36 Synoptic weather station synoptic data (15 stations in West Azerbaijan province, 12 stations in East Azerbaijan province and 


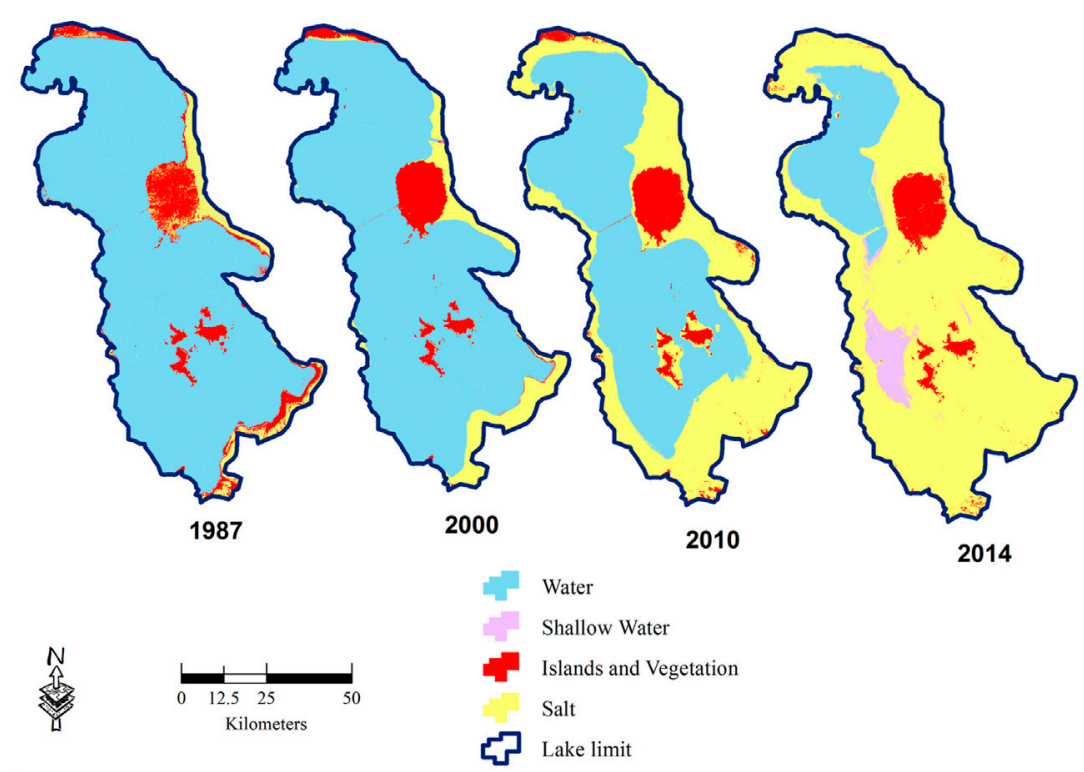

FIGURE 3 | Land-use class changing from 1987 to 2014 (author's illustration).

\begin{tabular}{|c|c|c|c|c|c|c|c|c|}
\hline \multirow[t]{2}{*}{ Land-use } & \multicolumn{2}{|c|}{1987} & \multicolumn{2}{|c|}{2000} & \multicolumn{2}{|c|}{2010} & \multicolumn{2}{|c|}{2014} \\
\hline & Area (H) & Percent & Area $(\mathbf{H})$ & Percent & Area (H) & Percent & Area $(\mathbf{H})$ & Percent \\
\hline Water & 482571.13 & 83.66 & 472562.42 & 81.93 & 310001.40 & 53.74 & 91988.32 & 15.95 \\
\hline Shallow water & 0.00 & 0.00 & 0.00 & 0.00 & 0.00 & 0.00 & 25001.24 & 4.33 \\
\hline Island and vegetation & 54578.82 & 9.46 & 42709.94 & 7.40 & 41474.47 & 7.19 & 34508.66 & 5.98 \\
\hline Salt & 39656.99 & 6.88 & 61534.59 & 10.67 & 225331.08 & 39.07 & 425308.72 & 73.74 \\
\hline Sum & 576806.95 & 100.00 & 576806.95 & 100.00 & 576806.95 & 100.00 & 576806.95 & 100.00 \\
\hline
\end{tabular}

nine station in Kurdistan province) in basin LU are used from 1987 to 2014 .

The result of precipitation in three provinces in northwest of Iran, show that the mean precipitation in 1987 were $471.6,291.7$ and $476.1 \mathrm{~mm}$ and this changed to 416,323 and $408 \mathrm{~mm}$ in 2014 for East Azerbaijan, West Azerbaijan and Kurdistan provinces, respectively. The mean precipitation in LU basin (in three provinces) is changed from 413 to $382 \mathrm{~mm}$ in the same period.

As you can see in Table 4; Figure 5, the precipitation has changed in 1987-2014 and the maximum precipitation was $555.65 \mathrm{~mm}$ for 1994 and the minimum was $278.95 \mathrm{~mm}$ for 1999 .

Assessment of temperature changes in the study period, show that annual average temperature changed from $12.85^{\circ} \mathrm{C}$ in 1987 to $13.19^{\circ} \mathrm{C}$ in 2014 . The maximum annual mean temperature in this period was $14.31^{\circ} \mathrm{C}$ in 2010 , and the minimum was $9.68^{\circ} \mathrm{C}$ in 1992. The temperature changes (s. Table 3 and Figure 6) were not dramatic and influential for a possible evapotranspiration increase in these periods. The results show that the slight decreasing of precipitation and the little increasing of temperature, not explain the dramatic water loss of LU, beside it marginally contributes.

\section{Human Factors}

Influential factors for LU drying are the dam construction in watersheds for agricultural land irrigation, the changed pattern of cultivation, especially the increasing irrigation in general, and reducing of ground water table by deep wells to increase the water consummation for agricultural irrigation.

\section{Dam Construction in Watersheds}

The main water sources for LU are Zarinerod, Ajichay, Simineroud, Zoulachay, Shahrchay, Leylanchay, Nazlochay, Barandouzchay, Sofichay, Galachay, Almalochay and Oskochay, which originate from the mountains around the lake (Sabalan, Sahand, the Mountains in Iran and Turkey boundary). The ecosystem of this lake is a typical example of a closed catchment area that drains all runoffs in the Basin Rivers. But today, construction of 48 dams (Garousi et al., 2013) has been constructed on the main rivers and main sources of lake water supply and it has caused a sharp decrease in the catchment water of the lake, which, with these unplanned dams and changing of river direction to the agricultural areas, surely the lake will go to dry. The total volume of water behind the dams is about 
TABLE 2 | Validation result (CL, PCM, KC \& RMS) in LTM model.

\begin{tabular}{lccc}
\hline $\mathbf{C L}$ & $\mathbf{P C M}$ & $\mathbf{K C}$ & $\mathbf{R M S}$ \\
\hline 100 & 72.84053 & 61.22500 & 0.13681 \\
200 & 73.06135 & 61.52973 & 0.13460 \\
300 & 73.24598 & 61.78236 & 0.13390 \\
400 & 73.57832 & 63.19273 & 0.13319 \\
500 & 73.75446 & 62.43834 & 0.13302 \\
600 & 73.56447 & 63.16961 & 0.13264 \\
700 & 73.43523 & 63.49482 & 0.13271 \\
800 & 74.26169 & 63.74834 & 0.13271 \\
900 & 74.39554 & 64.32832 & 0.13263 \\
1,000 & 74.61893 & 64.65109 & 0.13355 \\
1,500 & 74.78327 & 65.43641 & 0.13203 \\
2000 & 75.01406 & 66.22173 & 0.13182 \\
2,500 & 74.88482 & 65.56916 & 0.13160 \\
3,000 & 74.97936 & 65.65744 & 0.13154 \\
3,500 & 74.95867 & 65.66973 & 0.13155 \\
4,000 & 75.71590 & 66.32112 & 0.13140 \\
4,500 & 75.10638 & 66.84639 & 0.13146 \\
5,000 & 75.01868 & 67.69569 & 0.13134 \\
6,000 & 75.34179 & 67.15716 & 0.13134 \\
7,000 & 74.67249 & 68.22476 & 0.13128 \\
8,000 & 76.26979 & 69.11826 & 0.13134 \\
9,000 & 76.45904 & 70.24556 & 0.13091 \\
10,000 & 76.45443 & 69.26867 & 0.13110 \\
15,000 & 76.44230 & 70.21863 & 0.13104 \\
20,000 & 75.47606 & 68.61464 & 0.13099 \\
25,000 & 75.11336 & 68.34533 & 0.13101 \\
30,000 & 74.11567 & 68.02490 & 0.13100 \\
& & &
\end{tabular}

2.5 billion $\mathrm{m} 3$, about $13 \%$ of the lake's health capacity. By considering the extra flowing water prevented by dams (Figure 7), can clearly see the major impact of dams in the crisis (Lake Urmia Restoration Program, 2014).

\section{Changing the Pattern of Cultivation and Creating Unconventional Deep Wells}

In recent decades, increasing the number of crops that use too much water and especially water-based products has led to the need for water resources in the LU basin. The water-based farming in LU area increased from 350,000 to 500,000 ha (base of ULRP data) in 1987-2014. Also, the crops extensively change to many waters used crops, like beet sugar, apple (Lake Urmia Restoration Program, 2014). According to the analysis of resource condition and water consumption rate in the basin, by ULRP in 2014 at present, the total renewable water resources of the basin is about 7 billion cubic meters, while the total water uses is around 4.83 billion cubic meters of which 4.3 billion cubic meters is used in the agricultural sector, that is, the agricultural sector uses more than $60 \%$ of the whole renewable water resources and about $90 \%$ of the basin withdrawals. According to the United Nations Sustainable Development Index, the secure acceptable renewable water resources withdrawal should be between 20 and $40 \%$.

In addition to using the dam's water for agriculture, deep and semi-deep wells developed for increasing crops. According to the LU Restoration Program reports (2014); there are about 88,000 deep and semi-deep wells in the lake, which nearly half of these wells have been constructed illegally. With these challenges the runoff to the lake has tremendously reduced. Unfortunately,

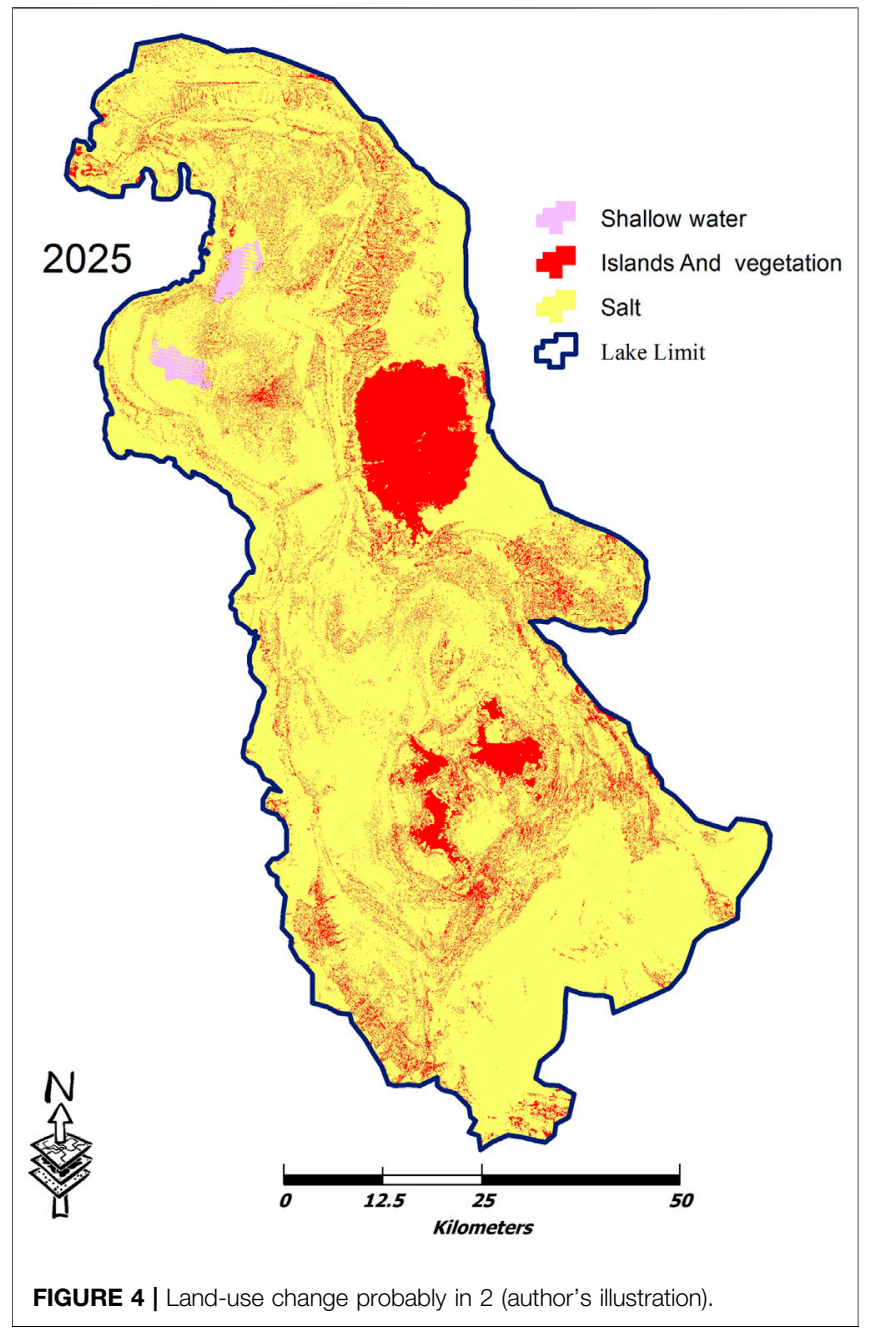

TABLE 3 | Simulation land-use change until 2025.

\begin{tabular}{lcc} 
Land-use & Percent & Area \\
\hline Water & 0.00 & 0.00 \\
Shallow water & 0.7 & $4,034.63$ \\
Islands and vegetation & 14.03 & 80930.40 \\
Salt & 85.27 & 491841.91 \\
Sum & 100.00 & 576806.95
\end{tabular}

density of these wells is much higher in Urmia and Miandoab plain that the main water resource for LU located in these plain (Lake Urmia Restoration Program, 2014).

Therefore, lake water drowning and reducing of underground water caused the blocking of a large part of the lake's water sources and has absorbed lake water by reducing underground aquifers.

\section{DISCUSSION}

Why the LU drying is an important and vital subject in Iran? 
TABLE 4 | Mean annual Precipitation and mean annual temperature in LU basin (East Azerbaijan, West Azerbaijan and Kurdistan provinces) from 1987 to 2014.

\begin{tabular}{|c|c|c|c|c|c|c|c|c|}
\hline \multirow[t]{2}{*}{ years } & \multicolumn{4}{|c|}{ Mean annual precipitation } & \multicolumn{4}{|c|}{ Mean annual temperature } \\
\hline & West Azerbaijan & East Azerbaijan & Kurdistan & Average in basin & West Azerbaijan & East Azerbaijan & Kurdistan & Average in basin \\
\hline 1987 & 471.69 & 291.79 & 476.10 & 413.19 & 12.16 & 12.99 & 13.39 & 12.85 \\
\hline 1988 & 461.33 & 308.54 & 462.17 & 410.68 & 10.89 & 11.99 & 11.90 & 11.59 \\
\hline 1989 & 313.66 & 211.14 & 363.83 & 296.21 & 11.75 & 12.49 & 12.00 & 12.08 \\
\hline 1990 & 323.66 & 194.41 & 296.64 & 271.57 & 11.44 & 12.10 & 11.84 & 11.79 \\
\hline 1991 & 497.00 & 284.64 & 425.46 & 402.37 & 11.45 & 12.16 & 11.44 & 11.69 \\
\hline 1992 & 506.57 & 276.93 & 559.97 & 447.82 & 9.02 & 10.45 & 9.55 & 9.68 \\
\hline 1993 & 628.97 & 356.73 & 652.82 & 546.17 & 9.64 & 10.39 & 11.36 & 10.46 \\
\hline 1994 & 600.70 & 331.80 & 734.45 & 555.65 & 11.13 & 11.66 & 12.25 & 11.68 \\
\hline 1995 & 399.54 & 227.18 & 479.28 & 368.67 & 11.67 & 12.58 & 11.92 & 12.06 \\
\hline 1996 & 426.40 & 260.56 & 509.13 & 398.70 & 11.72 & 12.70 & 12.01 & 12.14 \\
\hline 1997 & 422.07 & 225.40 & 528.40 & 391.96 & 10.87 & 11.78 & 11.21 & 11.29 \\
\hline 1998 & 399.07 & 225.27 & 469.77 & 364.70 & 12.42 & 12.95 & 12.69 & 12.68 \\
\hline 1999 & 292.50 & 226.17 & 318.17 & 278.95 & 13.03 & 13.20 & 13.09 & 13.11 \\
\hline 2000 & 357.07 & 211.47 & 416.49 & 328.34 & 12.35 & 12.97 & 12.55 & 12.62 \\
\hline 2001 & 331.53 & 204.25 & 355.60 & 297.13 & 12.83 & 13.58 & 13.18 & 13.19 \\
\hline 2002 & 449.14 & 305.01 & 577.76 & 443.97 & 12.48 & 12.60 & 12.02 & 12.37 \\
\hline 2003 & 486.32 & 305.87 & 539.19 & 443.79 & 12.07 & 12.40 & 12.08 & 12.18 \\
\hline 2004 & 452.38 & 329.73 & 556.31 & 446.14 & 11.89 & 12.80 & 12.12 & 12.27 \\
\hline 2005 & 329.20 & 250.41 & 443.30 & 340.97 & 11.91 & 12.60 & 12.07 & 12.19 \\
\hline 2006 & 489.34 & 321.53 & 612.65 & 474.51 & 12.38 & 12.77 & 12.69 & 12.61 \\
\hline 2007 & 377.33 & 276.60 & 444.94 & 366.29 & 11.84 & 11.88 & 12.36 & 12.03 \\
\hline 2008 & 310.74 & 212.03 & 320.61 & 281.13 & 12.35 & 12.49 & 12.66 & 12.50 \\
\hline 2009 & 390.86 & 277.45 & 495.11 & 387.81 & 12.30 & 12.53 & 12.19 & 12.34 \\
\hline 2010 & 347.46 & 277.45 & 433.51 & 352.81 & 14.27 & 14.42 & 14.24 & 14.31 \\
\hline 2011 & 463.24 & 338.90 & 504.03 & 435.39 & 11.59 & 11.67 & 11.95 & 11.74 \\
\hline 2012 & 412.50 & 305.37 & 483.78 & 400.55 & 12.75 & 12.83 & 12.64 & 12.74 \\
\hline 2013 & 376.84 & 262.45 & 452.06 & 363.78 & 12.31 & 12.63 & 12.71 & 12.55 \\
\hline 2014 & 416.01 & 323.88 & 408.80 & 382.90 & 13.14 & 13.29 & 13.13 & 13.19 \\
\hline
\end{tabular}

More than 7.1 million people (Statistical Center of Iran, 2011) live in East and West Azerbaijan who are affected by the drying of the lake. In the Lake basin, gardening and farming are the main sources of income and employment of residents. With the drying of the lake, salt storms from the open salt marshes affect the agricultural land in this area. Decreased of agricultural income by reduced soil fertility is an important factor for migration to cities outside the region, especially to large cities like Tabriz and Tehran. This contributes there to not easy to handle immigration problems.
The effects of LU drought could be classified in ecological, health, social and economic problems. Base of ULRP reports (2014) the most important effects or LU drying are:

- Storms of salt dust,

- Desertification and the vast expansion of desert areas in the region and the disappearing of natural areas

- Probability of spreading diseases in the region, including cardiovascular, ocular, pulmonary and others,

- Destruction of agricultural land and gardens, especially in the areas adjacent to the LU

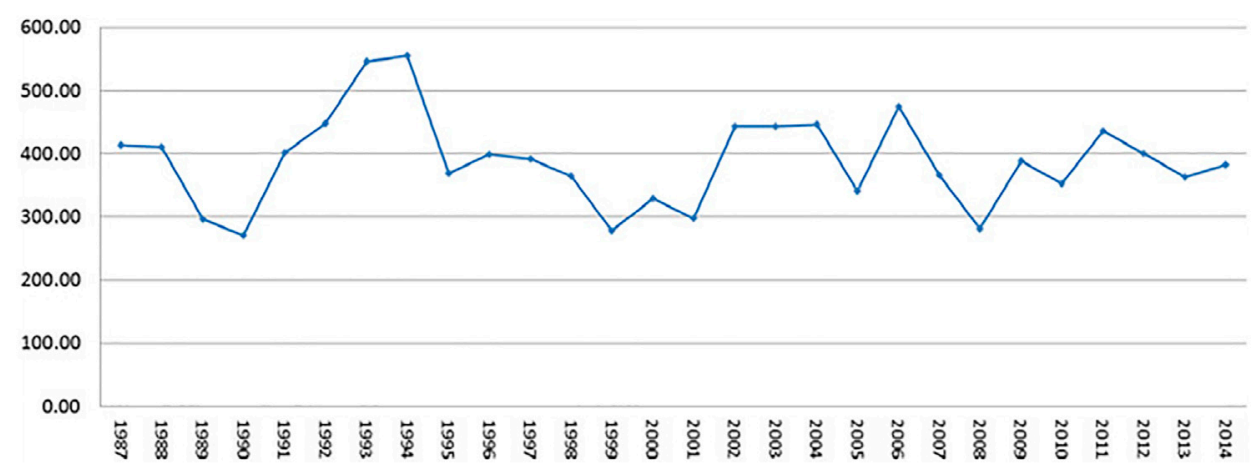

FIGURE 5 | Precipitation changes trends in LU basin from 1987 to 2014. 


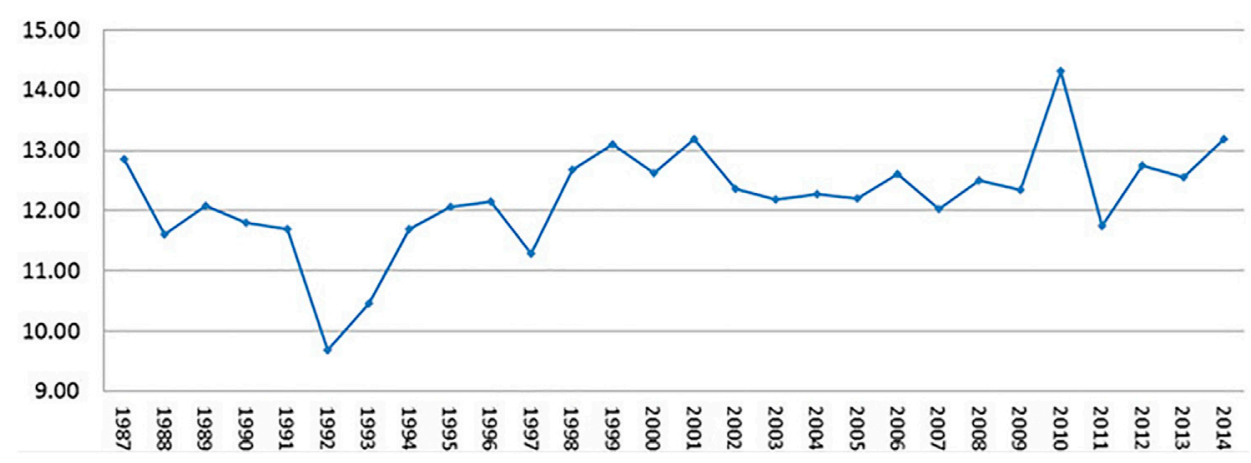

FIGURE 6 | Temperature changes in LU basin from 1987 to 2014.

- Increased animal diseases

- Regional climate change

The unique ecosystem of the lake will be changed completely parallel with salt increase. Another main problem is appearing a salt desert with area more than $5,000 \mathrm{~km}^{2}$ which has a $50-60 \mathrm{~cm}$ thick salt layer on the surface. When drought happens, the wind will transport the salt deposit them in the lake basin and to adjacent areas up to $300 \mathrm{~km}$ distance. This will damage agricultural lands, spoil the ecosystem and cause a variety of disease in nearby urban and rural areas (Hoseinpour et al., 2010). The same process is currently happening in nearly dried Aral Lake where winds eroded the lake basin and deposited ten million tons of salty dust on nearby habitats (Glantz, 1999).

As shown in Figure 8 if the drying up of LU continues, ecosystem changes will occur in East Azerbaijan, West Azerbaijan, Kurdistan and Zanjan provinces and part of Gilan and Kermanshah provinces.

\section{How to Reduce Water Consummation in the Lake Basin}

According to the Lake Urmia Restoration Program (2014) analysis of the water consumption of LU basin, total renewable water resources and consumption were more than 7

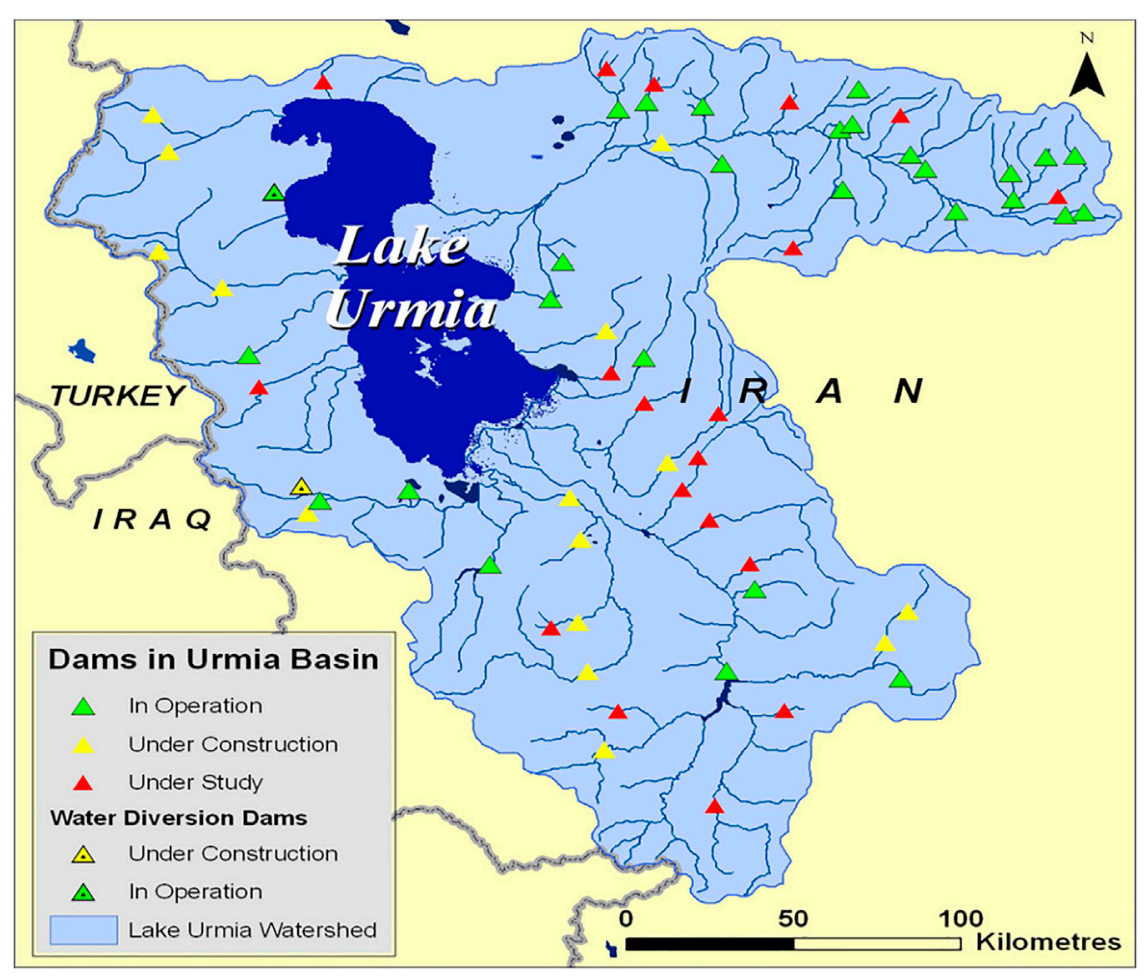

FIGURE 7 | The dams in LU catchment (Hassanzadeh et al., 2011). 


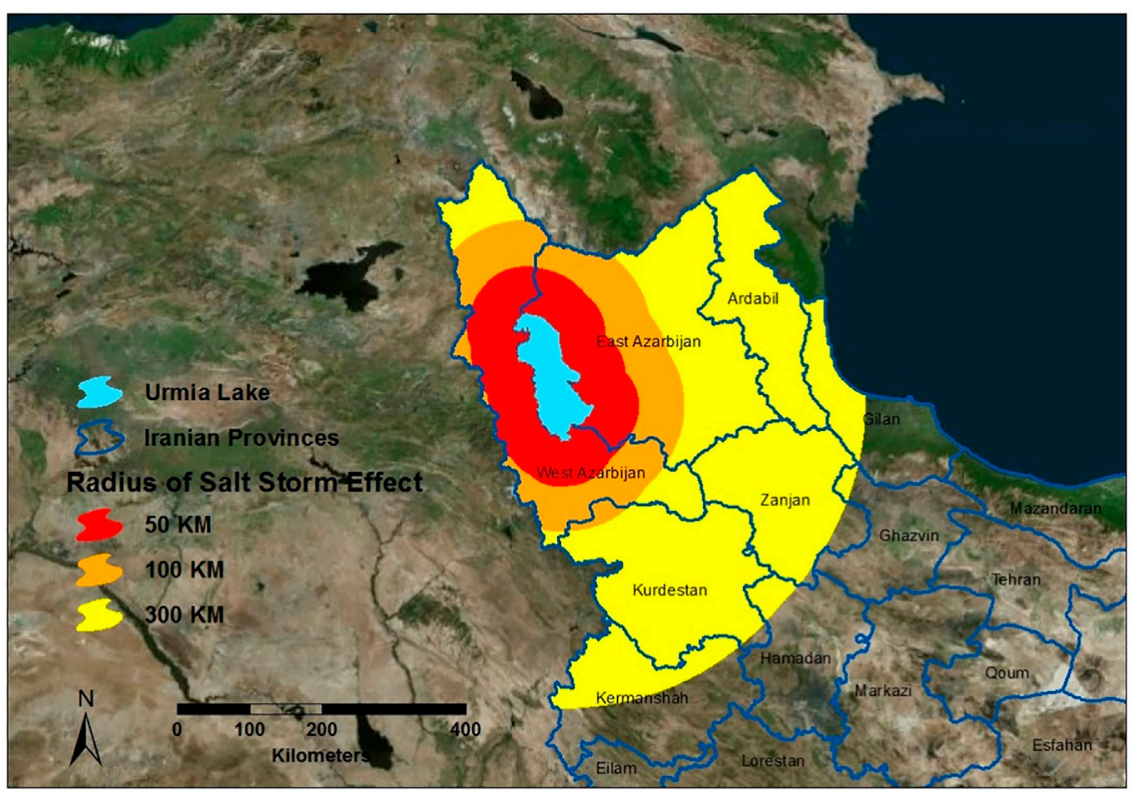

FIGURE 8 | Radius of Salt Storm Effect using ULRP reports (2014) (author's illustration).

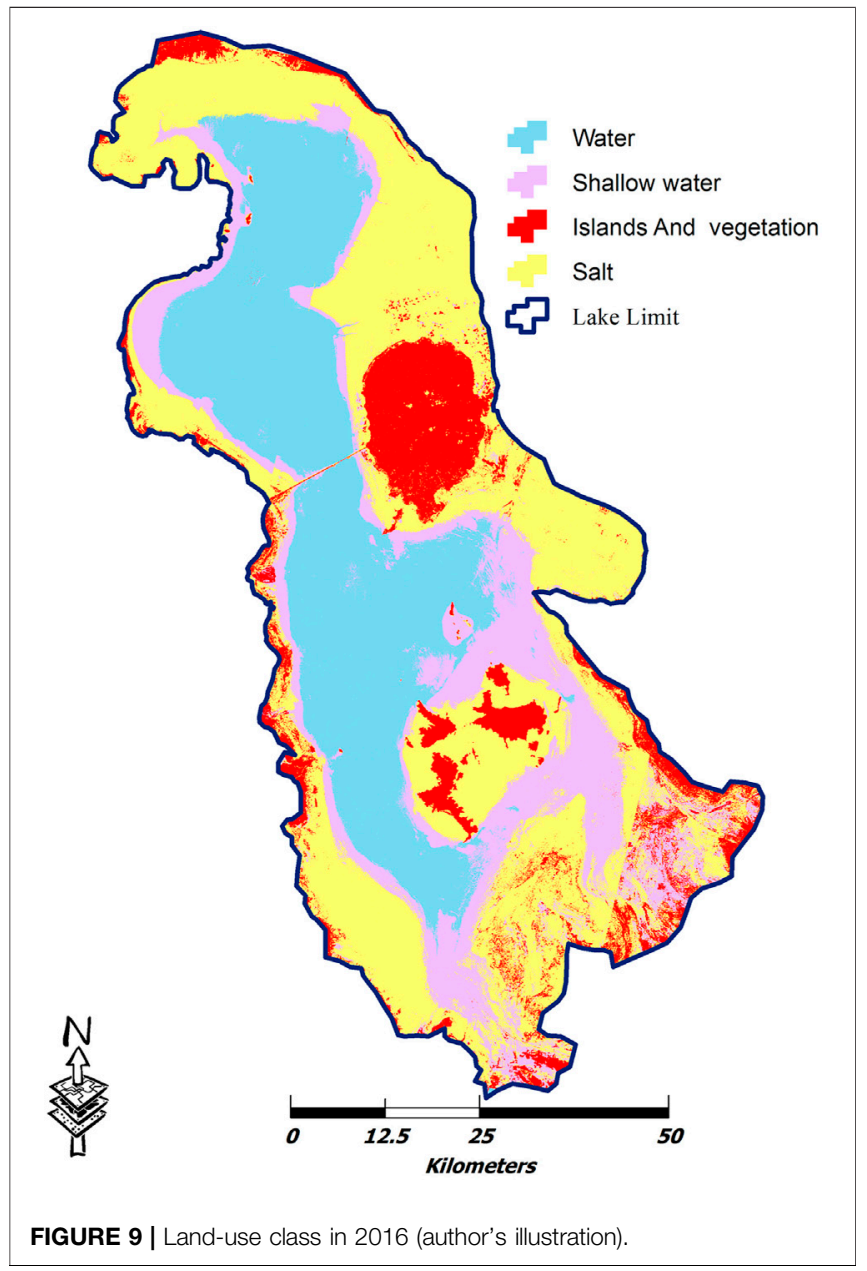

and 4.8 billion cubic meters, respectively. However, 4.3 billion cubic meters were consumed by agriculture.

The water consumption for human factors was $70 \%$ of the basin's renewable water resources, and the agricultural usage was approximately $60 \%$ of total renewable water resources and $90 \%$ of total water use in the basin. Due to the high-water consumption in the basin, the water areas have declined dramatically. So, an essential planning must be done to reduce water consumption in agriculture to save the lake. The ULRP studies (2014) show that best solution to establish an ecological balance for the lake is reducing $40 \%$ of agriculture water usage. To achieve this goal, the Jihad-agriculture Organization proposes to changing of cultivation and farming pattern such as: use of modern irrigation system instead of the traditional irrigation system and cultivating crops with low water demand. In East Azerbaijan, for reducing of water consummation, the Jehade-Agriculture Organization encourages the farmer to cultivate Saffron and Pistachios. This produce is low demanding water, and economical efficient and profitable (Iranian labour News Agency, 2014).

The second factor for water consumption, preventing the construction of new dams and temporarily opening dams in wet periods Also, if crop patterns change, most of the water stored in the dams can be released into LU.

TABLE 5 | Land-use in the LU area in 2016.

\begin{tabular}{lcc}
\hline Land-use & Percent & Area \\
\hline Water & 29.02 & 167367.45 \\
Shallow water & 18.26 & 105342.99 \\
Islands and vegetation & 12.69 & 73202.96 \\
Salt & 40.03 & 230893.55 \\
Sum & 100.00 & 576806.95
\end{tabular}




\section{Was Lake Urmia Restoration Program Successful?}

LU Restoration Program (ULRP) was established in 2013 to revitalize the lake and reduce the adverse effects of drying. This program started to increase the input water volume to the lake by release of stored water in the constructed dams, dredging of Simineh Roud, Godarchai, Mahabadchai and Ajichai rivers, connecting two major rivers Zarineh Roud and Simineh Roud for facilitating water delivery into the lake (Lake Urmia Restoration Program, 2015).

Evaluation of satellite images classification for 2016 show that the water areas in two recent years (2014-2016) increased (Figure 9; Table 5) due to ULRP activities. In 2016 dewatering of the lake was almost doubled compared to 2014 and various factors have been caused these positive changes in this period. Sufficient rainfall in the basin, the transfer of water from some rivers, opening of some dams and encouraging the cultivation of low-water demand crops are positive influences on the lake.

\section{CONCLUSION}

Land-use/cover change has a significant impact on regional and national ecological challenges. This paper evaluates the LU changes in recent decades, using Landsat images for analyzing of current condition, analyzing past changes and predicting the future changing in 2025 using LTM. The results indicated that in recent years due to natural and human factors, huge part of the water areas in LU has dried up and the salt marsh area in this period has increased. The results show that the rate of change in recent years, particularly between 2010 and 2014 was considerable intensity. In 2014 to 2016, dewatering in the lake has been updated due to favorable weather conditions, increased rainfall, proper dam's management and river water transfer to the lake. To

\section{REFERENCES}

Abbaspour, M., Javid, A. H., Mirbagheri, S. A., Ahmadi Givi, F., and Moghimi, P. (2012). Investigation of lake Drying Attributed to Climate Change. Int. J. Environ. Sci. Technol. 9 (2), 257-266. doi:10.1007/s13762-012-0031-0

AghaKouchak, A., Norouzi, H., Madani, K., Mirchi, A., Azarderakhsh, M., Nazemi, A., et al. (2015). Aral Sea Syndrome Desiccates Lake Urmia: Call for Action. J. Great Lakes Res. 41 (1), 307-311. doi:10.1016/j.jglr.2014.12.007

Ahmadi, A., Abbaspour, M., Arjmandi, R., and Abedi, Z. (2016). Resilient Approach toward Urban Development in lake Catchments, Case of Urmia Lake. Scientia Iranica 23 (4), 1627-1632. doi:10.24200/sci.2016.2233

Alborzi, A., Mirchi, A., Moftakhari, H., Mallakpour, I., Alian, S., Nazemi, A., et al. (2018). Climate-informed Environmental Inflows to Revive a Drying lake Facing Meteorological and Anthropogenic Droughts. Environ. Res. Lett. 13 (8), 084010. doi:10.1088/1748-9326/aad246

Allen, K., Corre, M. D., Kurniawan, S., Utami, S. R., and Veldkamp, E. (2016). Spatial Variability Surpasses Land-Use Change Effects on Soil Biochemical Properties of Converted lowland Landscapes in Sumatra, Indonesia. Geoderma 284, 42-50. doi:10.1016/j.geoderma.2016.08.010

Balkanlou, K. R., Müller, B., Cord, A. F., Panahi, F., Malekian, A., Jafari, M., et al. (2020). Spatiotemporal Dynamics of Ecosystem Services Provision in a illustrate the severity of the crisis, land-use/cover change for 2025 was modeled using changes 2010 to 2014 as a base and final map respectively. The modeling result indicated the future crises in LU and if decision makers don't change policies in these areas, the northwest of Iran will face irreparable consequence such as health, social and natural hazards. Therefore, the recommendations in this work for restoration of $\mathrm{LU}$ are change of pattern cultivation and cultivating crops with low water demand, use of modern irrigation system instead of the traditional irrigation system, establish the necessary regulations to release part of the dam water to the lake, Manage deep and semi-deep wells and prevent the construction of new wells.

\section{DATA AVAILABILITY STATEMENT}

The original contributions presented in the study are included in the article/supplementary materials, further inquiries can be directed to the corresponding author.

\section{ETHICS STATEMENT}

Ethical review and approval was not required for the study on human participants in accordance with the local legislation and institutional requirements. The patients/participants provided their written informed consent to participate in this study. Written informed consent was obtained from the individual(s) for the publication of any potentially identifiable images or data included in this article.

\section{AUTHOR CONTRIBUTIONS}

All authors listed have made a substantial, direct, and intellectual contribution to the work and approved it for publication.

Degraded Ecosystem: A Systematic Assessment in the Lake Urmia basin, Iran. Sci. Total Environ. 716, 137100-137113. doi:10.1016/ j.scitotenv.2020.137100

Breuste, J., and Qureshi, S. (2011). Urban Sustainability, Urban Ecology and the Society for Urban Ecology (SURE). Urban Ecosyst. 14 (3), 313-317. doi:10.1007/s11252-011-0186-3

Breuste, J., and Rahimi, A. (2015). Many Public Urban parks, but Who Profits from Them? the Example of Tabriz, Iran. Ecol. Process. 4 (6), 1-15. doi:10.1186/ s13717-014-0027-4

Danesh-Yazdi, M., and Ataie-Ashtiani, B. (2019). Lake Urmia Crisis and Restoration Plan: Planning without Appropriate Data and Model Is Gambling. J. Hydrol. 576, 639-651. doi:10.1016/j.jhydrol.2019.06.068

De Rosa, M. (2018). Land Use and Land-Use Changes in Life Cycle Assessment: Green Modelling or Black Boxing?. Ecol. Econ. 144, 73-81. doi:10.1016/ j.ecolecon.2017.07.017

Department of forestry and natural resources in university of Purdue (2018). Land Transformation Model. Available at: http://ltm.agriculture.purdue.edu/default_ ltm.htm.

Eimanifar, A., and Mohebbi, F. (2007). Urmia Lake (Northwest Iran): a Brief Review. Saline Syst. 3 (5), 1-8. doi:10.1186/1746-1448-3-5

Garousi, V., Najafi, A., Samadi, A., Rasouli, K., and Khanaliloo, B. (2013). "Environmental Crisis in Lake Urmia, Iran: A Systematic Review of Causes, 
Negative Consequences and Possible Solutions," in Proceedings of the 6th International Perspective on Water Resources \& the Environment (IPWE) Conference, Izmir, Turkey. doi:10.13140/RG.2.1.4737.0088

Ghale, A. G. Y., Baykara, M., and Unal, A. (2017). Analysis of Decadal Land Cover Changes and Salinization in Urmia Lake Basin Using Remote Sensing Techniques. Nat. Hazards Earth Syst. Sci. Discuss.. doi:10.5194/nhess-2017-212

Glantz, M. H. (1999). Creeping Environmental Problems and Sustainable Development in the Aral Sea Basin. Cambridge: Cambridge University Press.

Hassanzadeh, E., Zarghami, M., and Hassanzadeh, Y. (2011). Determining the Main Factors in Declining the Urmia Lake Level by Using System Dynamics Modeling. Water Resour. Manage. 26 (1), 129-145. doi:10.1007/s11269-011-9909-8

Hoseinpour, M., Fakherifard, A., and Naghili, R. (2010). Death of Lake Urmia , a Silent Disaster Investigating of Causes, Results and Solutions of Lake Urmia Drying. Iran: The 1st International Applied Geological Congress, Department of Geology, Islamic Azad University - Mashad Branch, 26-28.

Hossein Mardi, A., Khaghani, A., MacDonald, A. B., Nguyen, P., Karimi, N., Heidary, P., et al. (2018). The Lake Urmia Environmental Disaster in Iran: A Look at Aerosol Pollution. Sci. Total Environ. 633, 42-49. doi:10.1016/ j.scitotenv.2018.03.148

Iranian labour News Agency (Ilna) (2014). Cultivation of Saffron, Pistachios and Herbs Replaces Other Crops in Lake Urmia. Available at: https://www.ilna. news/fa/tiny/news-204544.

Jensen, J. R. (1996). Introductory Digital Image Processing: A Remote Sensing Perspective. Second Edition. Upper Saddle River New Jersey: Prentice-Hall, 316.

Jeong, J. S. (2018). Design of Spatial PGIS-MCDA-Based Land Assessment Planning for Identifying Sustainable Land-Use Adaptation Priorities for Climate Change Impacts. Agric. Syst. 167, 61-71. doi:10.1016/j.agsy.2018.09.001

Khazaei, B., Khatami, S., Alemohammad, S. H., Rashidi, L., Wu, C., Madani, K., et al. (2019). Climatic or Regionally Induced by Humans? Tracing HydroClimatic and Land-Use Changes to Better Understand the Lake Urmia Tragedy. J. Hydrol. 569, 203-217. doi:10.1016/j.jhydrol.2018.12.004

Kolmogorov, A. N. (1957). On the Representation of Continuous Functions of many Variables by Superposition of Continuous Functions of One Variable and Addition. Doklady Akademii Nauk SSR 114, 953-956.

Lake Urmia Restoration Program (ULRP) (2014). Lake Urmia, Causes of Drought and Possible Threats. Tehran. Iran: Lake Urmia Revival Headquarters.

Lake Urmia Restoration Program (ULRP) (2015). Restoration Plan of Lake Urmia Review of Approved Solutions. Tehran. Iran: administrative situation and progress projects.

Lee, H. Y. (2008). An Analysis on Development Capacity of an Urbanized Area for Urban Growth Management. J. Korean Urban Geographical Soc. 11 (1), 1-18. (in Korean).

López, E., Bocco, G., Mendoza, M., and Duhau, E. (2001). Predicting Land-Cover and Land-Use Change in the Urban Fringe. Landscape Urban Plann. 55 (4), 271-285. doi:10.1016/S0169-2046(01)00160-8

Nikraftar, Z., Parizi, E., Hosseini, S. M., and Ataie-Ashtiani, B. (2021). Lake Urmia Restoration success story: A Natural Trend or a Planned Remedy?. J. Great Lakes Res. 47, 955-969. doi:10.1016/j.jglr.2021.03.012

Pengra, B. (2012). The Drying of Iran's Lake Urmia and its Environmental Consequences. UNEP-GRID, Sioux Falls, UNEP Global Environmental Alert Service (GEAS).

Pijanowski, B. C., Gage, D. T., Long, D., and Cooper, W. C. (2000). “A Land Transformation Model: Integrating Policy, Socioeconomics and Environmental Drivers Using a Geographic Information System," in Landscape Ecology: A Top-Down Approach. Editors L. Harris and J. Sanderson (Boca Raton: Lewis Publishers).

Rahimi, A. (2016). A Methodological Approach to Urban Land-Use Change Modeling Using Infill Development Pattern-A Case Study in Tabriz, Iran. Ecol. Process. 5 (1), 1-15. doi:10.1186/s13717-016-0044-6

Rahimi, A. (2013). Assessment and Modeling of Spatial Development, with the Emphasis on Infill 398 Development: The Case of Metropolis Tabriz. Tabriz, Iran: Tabriz University.

Rasouli, A. A., Shirzad, A ., and Saed, J. (1998). Monitoring of Lake Urmia Water Level Fluctuations by Processing Multi-Sensor Satellite Images. J. Moderator Hum. Sci. 2, 53-71.

Rokni, K., Ahmad, A., Selamat, A., and Hazini, S. (2014). Water Feature Extraction and Change Detection Using Multitemporal Landsat Imagery. Remote Sensing 6, 4173-4189. doi:10.3390/rs6054173
Saemian, P., Elmi, O., Vishwakarma, B. D., Tourian, M. J., and Sneeuw, N. (2021). Analyzing the Lake Urmia Restoration Progress Using Ground-Based and Spaceborne Observations. Sci. Total Environ. 739, 139857. doi:10.1016/ j.scitotenv.2020.139857

Shadkam, S., Ludwig, F., van Vliet, M. T. H., Pastor, A., and Kabat, P. (2016). Preserving the World Second Largest Hypersaline lake under Future Irrigation and Climate Change. Sci. Total Environ. 559, 317-325. doi:10.1016/ j.scitotenv.2016.03.190

Sharifi, A., Shah-Hosseini, M., Pourmand, A., Esfahaninejad, M., and HaeriArdakani, O. (2018). The Vanishing of Lake Urmia : A Geolimnological Perspective on the Hydrological Imbalance of the World's Second Largest Hypersaline Lake. Berlin, Heidelberg: Springer. doi:10.1007/ 698_2018_359

Shirmohammadi, B., Malekian, A., Salajegheh, A., Taheri, B., Azarnivand, H., Malek, Z., et al. (2020). Scenario Analysis for Integrated Water Resources Management under Future Land Use Change in the Urmia Lake Region, Iran. Land Use Policy 90, 104299. doi:10.1016/ j.landusepol.2019.104299

Sima, S., Rosenberg, D. E., Wurtsbaugh, W. A., Null, S. E., and Kettenring, K. M. (2021). Managing Lake Urmia, Iran for Diverse Restoration Objectives: Moving beyond a Uniform Target lake Level. J. Hydrol. Reg. Stud. 35, 100812. doi:10.1016/j.ejrh.2021.100812

Statistical Center of Iran (2011). National Population and Housing Census. Available at: https://www.amar.org.ir/english.

Torabi, H., A., Fazel, N., Hekmatzadeh, A. A., and Klöve, B. (2018). Analysis of Effective Environmental Flow Release Strategies for Lake Urmia Restoration. Water Resour.Manag. 32 (11), 3595-3609. doi:10.1007/ s11269-018-2008-3

Tourian, M. J., Elmi, O., Chen, Q., Devaraju, B., Roohi, S., and Sneeuw, N. (2015). A Spaceborne Multisensor Approach to Monitor the Desiccation of Lake Urmia in Iran. Remote Sensing Environ. 156, 349-360. doi:10.1016/ j.rse.2014.10.006

United Nations Environment Programme (UNEP) (2012). The Drying of Iran's Lake Urmia and its Environmental Consequences. Available at: http://na.unep. net/geas/getUNEPPageWithArticleIDScript.php?article_id=79.

United States Geological Survey (USGS) (2018). EarthExplorer. Available at: https://earthexplorer.usgs.gov/.

Wang, Y., Dai, E., Yin, L., and Ma, L. (2018). Land Use/land Cover Change and the Effects on Ecosystem Services in the Hengduan Mountain Region, China. Ecosystem Serv. 34, 55-67. doi:10.1016/ j.ecoser.2018.09.008

Wine, M. L., Rimmer, A., and Laronne, J. B. (2019). Agriculture, Diversions, and Drought Shrinking Galilee Sea. Sci. Total Environ. 651, 70-83. doi:10.1016/ j.scitotenv.2018.09.058

Yapiyev, V., Samarkhanov, K., Tulegenova, N., Jumassultanova, S., Verhoef, A., Saidaliyeva, Z., et al. (2019). Estimation of Water Storage Changes in Small Endorheic Lakes in Northern Kazakhstan. J. Arid Environments 160, 42-55. doi:10.1016/j.jaridenv.2018.09.008

Zarghami, M. (2011). Effective Watershed Management; Case Study of Urmia Lake, Iran. Lake Reservoir Manage. 27 (1), 87-94. doi:10.1080/ 07438141.2010 .541327

Conflict of Interest: The authors declare that the research was conducted in the absence of any commercial or financial relationships that could be construed as a potential conflict of interest.

Publisher's Note: All claims expressed in this article are solely those of the authors and do not necessarily represent those of their affiliated organizations, or those of the publisher, the editors and the reviewers. Any product that may be evaluated in this article, or claim that may be made by its manufacturer, is not guaranteed or endorsed by the publisher.

Copyright $\odot 2021$ Rahimi and Breuste. This is an open-access article distributed under the terms of the Creative Commons Attribution License (CC BY). The use, distribution or reproduction in other forums is permitted, provided the original author(s) and the copyright owner(s) are credited and that the original publication in this journal is cited, in accordance with accepted academic practice. No use, distribution or reproduction is permitted which does not comply with these terms. 